\title{
AN EXAMINATION OF RETAILERS' COMPLIANCE WITH THE MINIMUM LEGAL DRINKING (PURCHASING) AGE LAW IN SLOVENIA: A QUASI-EXPERIMENTAL INTERVENTION STUDY
}

\section{PREVERJANJE SPOŠTOVANJA ZAKONA O OMEJEVANJU PORABE ALKOHOLA V SLOVENIJI: KVAZIEKSPERIMENTALNA INTERVENCIJSKA RAZISKAVA}

\author{
Tanja KAMIN ${ }^{*}$, Sinja ČOŽ ${ }^{1}$, Sara ATANASOVA ${ }^{1}$ \\ ${ }^{1}$ University of Ljubljana, Faculty of Social Sciences, Kardeljeva ploscad 5, 1000 Ljubljana, Slovenia
}

Received: Oct 15, 2020

Original scientific article

Accepted: Feb 1, 2021

\author{
ABSTRACT \\ Keywords: \\ alcohol availability, \\ mystery shopping, \\ youth, MLDA, law \\ enforcement, \\ interventions, \\ retailer compliance
}

\section{IZVLEČEK}

Ključne besede: dostopnost alkohola, skrito nakupovanje, mladi, ZOPA, izvajanje zakona, intervencije, delovanje trgovcev $v$ skladu z zakonom
Introduction: Alcohol consumption among young people is strongly related to alcohol availability. The minimum legal drinking (purchasing) age (MLDA) is a legal measure that regulates alcohol availability to minors in Slovenia. This study examines (1) retailers' compliance with the MLDA law in Slovenia and (2) the effectiveness of two interventions directed at cashiers in off-premise stores.

Methods: The study uses a non-randomized quasi-experimental design to evaluate the effectiveness of (1) a communication intervention directed at off-premise store managers, and (2) an intervention by the Slovene Market Inspectorate. The first intervention focused on informing cashiers about MLDA's importance and their role as gatekeepers of young people's health, while the second involved law enforcement. Using the mystery shopping protocol, we conducted two waves of purchase attempts with decoy underage shoppers pre- and post-intervention in 97 off-premise stores. We collected data on the shopping process at the point of sale and conducted 40 semistructured interviews with cashiers to evaluate the barriers and incentives regarding MLDA compliance.

Results: Retailers' initial noncompliance rate with MLDA in off-premise stores was high, but improved significantly after the law enforcement intervention. We identified a significant correlation between the cashiers' ID requests and the refusal of alcohol sales, but cashiers' ID requests remained low. Qualitative findings reveal that cashiers experience several issues when handling MLDA in practice.

Conclusion: Noncompliance with MLDA persisted even after the law enforcement intervention, revealing the need for policy makers to introduce new strategies for MLDA enforcement, such as revocable alcohol licenses for offpremise stores.

Uvod: Pitje alkohola med mladimi je močno povezano z dostopnostjo alkoholnih pijač. $V$ Sloveniji področje dostopnosti alkohola mladim uravnava Zakon o omejevanju porabe alkohola (ZOPA), ki v 7. členu prepoveduje prodajo alkoholnih pijač mlajšim od 18 let. Namen naše raziskave je bil preveriti (1) kako dosledno $v$ različnih trgovinah v Sloveniji upoštevajo zakonski ukrep o prepovedi prodaje alkoholnih pijač mladoletnim, in (2) učinkovitost dveh različnih intervenciji, namenjenih prodajalcem pri izboljšanju doslednosti izvajanja zakonskega ukrepa. Želeli smo pridobiti tudi boljše razumevanje prakse izvajanja zakonskega ukrepa s strani prodajalcev in prodajalk.

Metode: Raziskava je zasnovana na nenaključnem kvazieksperimentalnem pristopu $k$ raziskovanju. Osredotoča se na izvedbo (1) komunikacijske intervencije in (2) intervencije s Tržnim inšpektoratom Republike Slovenije. Prva intervencija prodajalce z intervencijskimi materiali opominja na pomembnost izvajanja ZOPA ter na njihovo vlogo pri skrbi za zdravje mladih. Druga intervencija je izvedena $v$ sodelovanju s Tržnim inšpektoratom. Z metodo skritega nakupovanja je bilo $v$ dveh valih - pred izvedbi intervencij in po njih - opravljenih 97 meritev poskusa nakupa alkoholne pijače z nastavljeno mladoletno osebo. Protokol za poskus nakupa alkoholne pijače je bil določen vnaprej, sodelujoči skriti kupci in opazovalci so bili zanj posebej usposobljeni. Da bi dobili boljši vpogled $v$ kontekst izvajanja ZOPA, smo z odprtim vprašanjem $v$ vprašalniku o nakupnem procesu zbrali poročila skritih kupcev o interakciji $v$ času poskusa nakupa. Opravili smo tudi 40 polstrukturiranih intervjujev s prodajalci o njihovih izkušnjah z izvajanjem ZOPA.

Rezultati: Meritve so pokazale visoko stopnjo neupoštevanja ZOPA prodajalcev $v$ različnih trgovinah $v$ šestih izbranih slovenskih mestih. Stopnja upoštevanja ZOPA se je znatno izboljšala po intervencijah s Tržnim inšpektoratom RS. Izmerili smo korelacijo med zavrnitvijo nakupa alkoholne pijače mladoletni osebi in zahtevo po predložitvi osebnega dokumenta, a žal smo izmerili nizko stopnjo zahtev po predložitvi osebnega dokumenta tako pred intervencijami kot po njih. Iz intervjujev s prodajalci smo pridobili vpogled $v$ zaznane ovire in spodbude za spoštovanje ZOPA v praksi.

Zaključek: Kljub uspešnosti intervencij je upoštevanje ZOPA še vedno slabo, kar bi morda moralo politične akterje spodbuditi k dopolnitvi ZOPA in sankcij za njegovo neupoštevanje. Uvedba licenc za prodajalce alkoholnih pijač, ki so lahko v primeru kršitve ZOPA odvzete, bi lahko bila ena od dopolnitev. Morda bi to spodbudilo vodstva trgovskih verig, da svojim prodajalcem ponudijo usposabljanja s konkretnimi usmeritvami za prakso izvajanja zakonske dolžnosti. V Sloveniji se od prodajalcev zahteva, da sledijo ZOPA in zavrnejo prodajo alkoholne pijače mladoletni osebi.

\footnotetext{
*Corresponding author: E-mail: tanja.kamin@fdv.uni-lj.si
} 


\section{INTRODUCTION}

Alcohol consumption is strongly embedded in Slovene culture (1-5), and alcoholic beverages are easily accessible to the general population as well as young people $(5,6)$. Therefore, to reduce alcohol consumption in Slovenia, we need to approach the problem by cooperating with multiple stakeholders $(2,7,8)$. The WHO recommends taking several evidence-based actions, with limits on the physical availability of alcoholic beverages (by restricting sales to certain days/hours, increasing the age limit for the purchase and use of alcoholic beverages, etc.) being considered one of the most effective policy measures, along with the reduced affordability of alcoholic beverages $(2,9)$. The assumption is that restricting availability will reduce the demand for alcoholic beverages by increasing the effort needed to obtain them (10).

Studies demonstrate that alcohol availability influences teenage drinking patterns (10) through the direct availability of alcohol (11) and by influencing the norms, attitudes and personal beliefs about drinking (12), as alcohol availability strengthens the perception that alcohol consumption at any time and for every occasion is normal (13) or even encouraged (12, 14, 15). In Slovenia, alcohol consumption among young people remains high by international standards: $27 \%$ of 15 -year-olds and $52 \%$ of 17-year-olds report having been drunk at least twice in their life (16). Young people obtain alcoholic beverages in various settings: at home, at school, from their friends and in commercial locations, such as bars, food stores and gas stations (5). It should be impossible for minors to purchase alcohol in commercial settings because alcohol availability is regulated via the minimum legal drinking (purchasing) age (MLDA) (17). MLDA obliges offpremise sellers (e.g. supermarkets) to check the age of purchasers attempting to buy alcoholic beverages and to refuse sales if purchasers do not meet the minimum age (18 years in Slovenia). While the legal restrictions with regard to alcohol-related behaviours appear to be sound on paper, they are often not accompanied by effective enforcement strategies for encouraging deliberate compliance with the law (18). Moreover, previous studies have shown that MLDA can be very efficient (2), especially if law enforcement agencies check MLDA compliance and sanction the offending alcohol sellers more frequently (19-24). However, as the positive effects of increased law enforcement interventions fade over time (19), such interventions should be performed more than twice per year $(19,21,24)$. Since this is often unfeasible $(24,25)$, less repressive interventions for reducing MLDA violations (18, 26) - for example, improving the sellers' understanding of MLDA's social function - could be more efficient (17).
A study with a representative sample examining alcohol purchases among youth in Slovenia reported that $85 \%$ of those aged 15-16 years thought that alcohol was fairly easy to obtain (no differences between genders), and that $17.6 \%$ of those aged $15-16$ had purchased an alcoholic beverage in an off-premise store at least once in the past month (6). Similar results were reported by another study, which showed that only one third of the children aged 12-15 years reported difficulties with buying alcohol in off-premise stores in Slovenia, with younger respondents reporting fewer problems with the purchase than the older ones (5).

Our study, supported by the Slovene Ministry of Health and conducted in collaboration with the Slovene youth organisation No Excuse Slovenia, aims to improve the understanding of the implementation of MLDA in offpremise stores in Slovenia.

This study investigates (1) the MLDA compliance rate, (2) the potential effectiveness of two interventions designed to encourage MLDA compliance, and (3) the circumstances that influence MLDA compliance from the perspective of those who are obliged to apply MLDA in their daily practices, namely the cashiers.

\section{METHODS}

\subsection{Research design}

We studied retailers' MLDA compliance and the potential effectiveness of two interventions meant to improve this. We conducted a non-randomized quasi-experimental study with two experimental groups and one control group.

The study was implemented in three stages between December 2018 and June 2019 (Figure 1):

(1) Pre-intervention measures: we used a quantitative data collection approach based on the mystery shopping protocol to measure retailers' MLDA compliance.

(2) Interventions to increase retailers' MLDA compliance, namely the communication intervention and the intervention by the Slovene Market Inspectorate (SMI).

(3) Post-intervention measures: we used a quantitative data collection approach based on the mystery shopping protocol to evaluate the effects of the two interventions. 


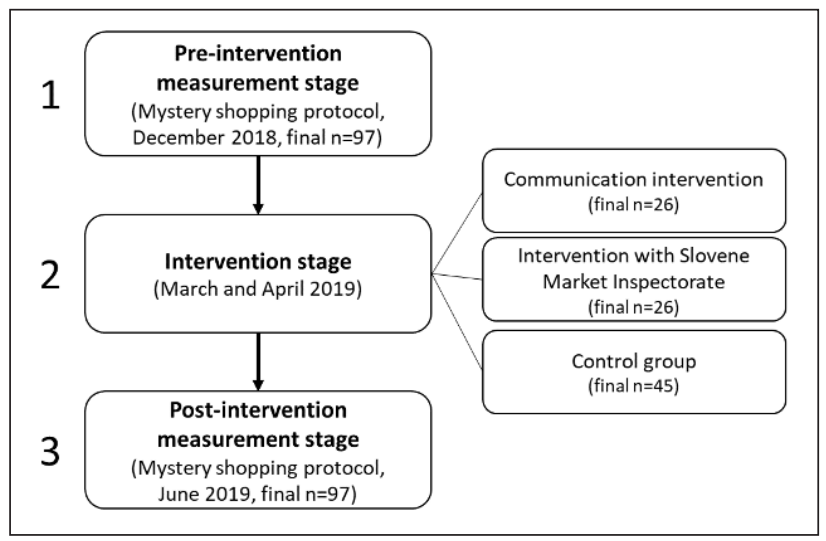

Figure 1. Stages of the Non-Randomized Quasi-Experimental Study.

We purposively selected stores from six retail chains in the following six major cities from different Slovene regions: Ljubljana, Maribor, Kranj, Celje, Novo mesto and Koper. All retail chains in our sample (Mercator, Spar, Hofer, Lidl, Tuš and Eurospin) had stores in all selected cities, and shared similar characteristics: they were privately owned, had similar hierarchical structures and sold alcoholic beverages off-premises.

\subsection{Sampling procedure}

We used a non-randomized sampling technique to select 100 retail stores across the six selected cities (Table 1). We split the sample evenly into three study groups (two intervention groups and one control group). During the communication intervention, we visited 66 stores with an invitation to cooperate. We added the stores that refused to cooperate to the control group. Intervention visits by the Inspectorate were planned for 34 stores. The Inspectorate conducted law enforcement checks in the branches of one retail chain in one city until the purchase of the alcoholic beverage was successful. After a successful purchase, they no longer visited the branches of that specific retail chain in that city. Due to the Inspectorate's protocol, eight stores were never visited, and we added them to the control group.

The sample was divided into the following three study units (Figure 1): (1) experimental group for the communication intervention; (2) experimental group for the SMI intervention; and (3) control group, without intervention.

\subsection{Data collection}

The data collection procedure involved quantitative data collection based on the mystery shopping protocol (Figure 1) and included a questionnaire. By following the mystery shopping protocol, we collected data on MLDA compliance before and after the interventions. The mystery shopper was a minor, escorted by an adult observer. In total, 25 people participated as mystery shoppers (aged $16-17$ years, average age 16 years) and observers (aged 20-29 years). The parents of the minors who participated as mystery shoppers provided written informed consent. Mystery shoppers and observers were recruited via the Slovene youth organisation No Excuse Slovenia; observers were selected according to their prior experience in the field of alcohol-harm reduction and received mystery shopping training. We ensured in advance that the underage participants followed the dress codes appropriate to their actual age.

To ensure that the results of mystery shopping were comparable, we used the following set protocol: the mystery shopper selected a 0.5 -litre can of beer and a snack and tried to make a purchase. If a cashier asked them about their age, the mystery shoppers were instructed to lie and say they were 18 years old. If a cashier asked for an ID, the mystery shoppers were instructed to show their real valid IDs. The observer discreetly monitored the process from a safe distance to avoid being identified as accompanying the purchaser. If the transaction was successful, the observer collected the purchased alcohol. Together with the mystery shopper, the observer filled out a questionnaire immediately after each mystery shopping visit.

The questionnaire included 30 questions about the basic characteristics of the mystery shopper (gender and age), the characteristics of the visited store (name, address, size, date and hour of the visit, number and type of cash registers) and the characteristics of the cashier (gender and approx. age). Seven yes/no questions asked the mystery shopper and the observer to describe the interaction with the cashier (e.g. "Did the cashier ask about the mystery shopper's age?", "Did the cashier ask for the mystery shopper's ID?"). The mystery shopper and the observer were also asked (in an open-ended question) to summarize the interaction with the cashier. The questionnaire included ten additional questions that were not analysed for this article. The questionnaire was used and validated in a previous intervention study (18).

To gain a better understanding of MLDA compliance from a cashier's perspective, we also conducted 40 additional semi-structured interviews with persons working as cashiers (29 of the participants were also retail managers). We collected this data in November 2019, once quantitative data collection was complete, in the same retail chains and cities to better interpret the quantitative data. For the qualitative inquiry we used a convenience sampling technique and interviewed the cashiers who worked during our visits to the stores, and who gave verbal consent to participate in the interview about MLDA compliance in practice. The length of the interviews varied between five and 50 minutes, with the 
average length being 12 minutes. The researcher and assistant wrote down notes during the interviews because the respondents did not agree to audio recordings due to the sensitivity of the focal topic. After the interviews, these notes were prepared for the analysis.

\subsection{Intervention procedure}

In the intervention stage of the study, we carried out communication interventions and interventions with the SMI to increase retailers' MLDA compliance.

\subsubsection{Communication intervention}

This intervention was based on the communication part of the Slovene social marketing program 18 Rules! from 2014, which was successful in increasing MLDA compliance (18). We developed materials to help cashiers improve their understanding of MLDA's importance and make them recognize the importance of their role in safeguarding young people's health.

We asked the higher management of the selected retail chains for approval to conduct the interventions with cashiers in the chosen stores. With the exception of Spar, we were not allowed to have direct contact with the cashiers. Therefore, we disseminated only two of the planned intervention materials: folding leaflets and a poster with a comic depicting a superhero, meant to help cashiers feel more empowered when implementing MLDA, as previous research has shown that cashiers consider their role as an 'ID checker' to be very stressful and unrewarding (18).

Two project assistants were trained to approach the lower management of the retail chains' branches with the intervention materials (150 folding leaflets and two posters), explaining their purpose and asking the lower management to participate in the project by giving the materials to their cashiers.

\subsubsection{Intervention by Slovene market inspectorate}

The intervention by the SMI used the mystery shopping method, whereby a trained underaged shopper tried to purchase an alcoholic beverage, accompanied by an undercover inspector. If the purchase of the alcoholic beverage was successful, meaning the cashier did not comply with MLDA, the inspector revealed himself and gave the penalty prescribed by the law. If the purchase by the minor was unsuccessful, the inspector remained undercover.

\subsection{Data analysis}

Quantitative data were analysed using univariate and bivariate data analysis techniques. To examine retailers' MLDA compliance and the effectiveness of the two interventions directed at cashiers in off-premise stores, we closely observed the relationship between the following three variables that are closely related to MLDA compliance: (1) the number of times that alcohol was sold to the underaged mystery shopper, (2) the number of times that a cashier asked about the mystery shopper's age, and (3) the number of times that a cashier asked to see the mystery shopper's ID. The data were analysed using IBM SPSS and MS Excel.

The qualitative data collected after the conclusion of the quantitative study was analysed via the descriptive level of thematic analysis, which is the first, basic stage of thematic analysis (27). Two researchers read through the data, identified recurring answers across the data set, agreed on the common issues conveyed by the respondents and summarized the findings in a descriptive report.

\section{RESULTS}

\subsection{Sample characteristics}

The sample for the data analysis consisted of 97 retail stores (one store was excluded from the sample as it closed down between the two measurement stages, and two stores were excluded due to a loss of the completed questionnaires and thus missing values), of which 26 stores received the communication intervention. The SMI visited 26 stores, with the inspector revealing himself on 18 occasions. The control group consisted of 45 stores (for the distribution between cities, see Table 1).

\subsection{Pre-intervention measures}

The results of the pre-intervention measures revealed a high rate of alcohol sales to minors (mystery shoppers), indicating low MLDA compliance. As demonstrated in Table 2, the overall rate of alcohol sales to minors was $88.7 \%$, with the figure varying between cities, and the most problematic cities being Novo mesto and Celje (both with a rate of $100 \%$ ). 
Table 1. The number of retail stores according to intervention type and city.

\begin{tabular}{|c|c|c|c|c|c|}
\hline \multirow[t]{3}{*}{ City } & \multicolumn{4}{|c|}{ Intervention type } & \multirow{3}{*}{ Total } \\
\hline & \multirow{2}{*}{$\begin{array}{l}\text { Communication } \\
\text { intervention }\end{array}$} & \multicolumn{2}{|c|}{ Intervention by the SMI } & \multirow[t]{2}{*}{ Control group } & \\
\hline & & Std. B & $\mathbf{P}$ & & \\
\hline Ljubljana & 16 & 4 & 5 & 22 & 47 \\
\hline Maribor & 3 & 4 & 2 & 10 & 19 \\
\hline Kranj & 0 & 3 & 0 & 6 & 9 \\
\hline Koper & 2 & 1 & 1 & 2 & 6 \\
\hline Novo mesto & 1 & 3 & 0 & 3 & 7 \\
\hline Celje & 4 & 3 & 0 & 2 & 9 \\
\hline Total & 26 & 18 & 8 & 45 & 97 \\
\hline
\end{tabular}

Table 2. The rate of alcohol sales to minors (mystery shoppers) by city.

\begin{tabular}{lc}
\hline City & $\begin{array}{c}\mathrm{n}(\%) \text { of stores that sold alcohol } \\
\text { to minors }\end{array}$ \\
\hline Ljubljana & $40(85.1 \%)$ \\
Maribor & $18(94.7 \%)$ \\
Kranj & $7(77.8 \%)$ \\
Koper & $5(83.3 \%)$ \\
Novo mesto & $7(100.0 \%)$ \\
Celje & $9(100.0 \%)$ \\
Total & $86(88.7 \%)$ \\
\hline
\end{tabular}

Importantly, the results also revealed that in most cases the cashiers did not follow the standard MDLA protocol, which requires them to check the ID of anyone who does not look to be of legal age. Cashiers inquired about the shoppers' age in $17.5 \%$ of cases, and in $23.5 \%$ of the cases, they requested to see the ID. In most of these cases they still sold the alcohol to minors: 12 out of 17 purchases were successful after inquiring about the shopper's age, and 13 out of 23 purchases were successful even after asking to see the ID which showed that the shopped was underage.

\subsection{Post-intervention measures and the effects of the interventions}

The results of the post-intervention measures revealed an overall decrease of 9.3 percentage points in alcohol sales to minors. The total rate of sales to minors dropped to $79.4 \%$ (from $88.7 \%$ ), with the most notable decreases taking place in Maribor, Novo mesto and Celje (Table 3). It should be noted that the number of retail stores differed greatly between cities, and some had a very low number of stores in the sample.
Table 3. Comparison of the success rate of alcohol sales to minors (mystery shoppers) by city in the pre- and post-intervention measurement stages.

\begin{tabular}{lcc}
\hline City & $\begin{array}{c}\text { Pre-intervention } \\
\text { measurement stage: } \\
\mathrm{n}(\%) \text { of stores that } \\
\text { sold alcohol to minors }\end{array}$ & $\begin{array}{c}\text { Post-intervention } \\
\text { measurement stage: } \\
\mathrm{n}(\%) \text { of stores that } \\
\text { sold alcohol to minors }\end{array}$ \\
\hline Ljubljana & $40(85.1 \%)$ & $39(83.0 \%)$ \\
Maribor & $18(94.7 \%)$ & $12(63.2 \%)$ \\
Kranj & $7(77.8 \%)$ & $7(77.8 \%)$ \\
Koper & $5(83.3 \%)$ & $6(100.0 \%)$ \\
Novo mesto & $7(100.0 \%)$ & $5(71.4 \%)$ \\
Celje & $9(100.0 \%)$ & $8(88.9 \%)$ \\
Total & $86(88.7 \%)$ & $77(79.4 \%)$ \\
\hline
\end{tabular}

There was a decrease in alcohol sales in all experimental groups and no decrease in the control group (Figure 2). There was a small drop in alcohol sales (by 3.9 percentage points) in the group that received the communication intervention, with successful purchases decreasing from $96.2 \%$ to $92.3 \%$. A more significant drop took place in the group that received the intervention by the SMI, with a decrease of 27.7 percentage points in the group where the inspector revealed himself and a decrease of 50 percentage points (from $87.5 \%$ to $37.5 \%$ ) in the group where the inspector remained undercover. 


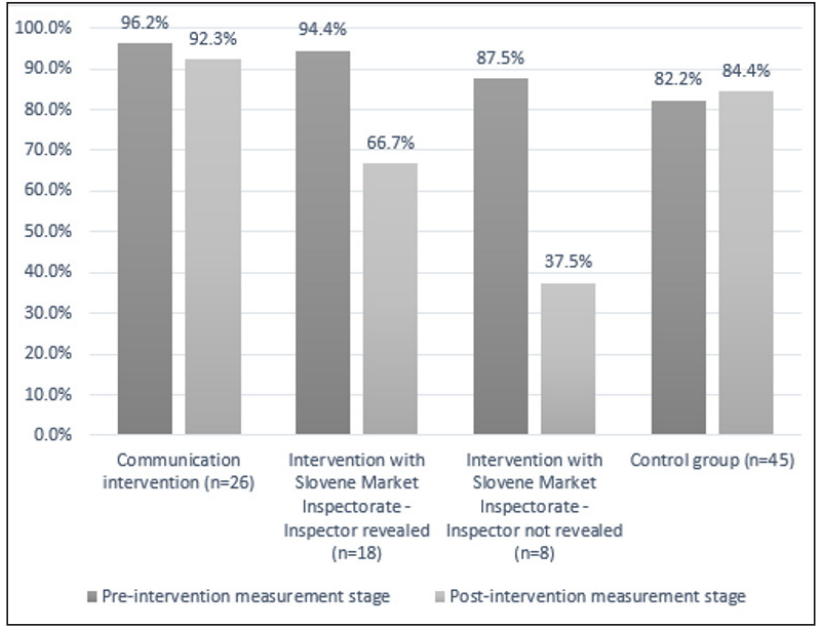

Figure 2. The rate of alcohol sales to minors (mystery shoppers) according to intervention type in the pre- and post-intervention measurement stages.

In the post-intervention measurement stage there was also an improvement in cashiers' MLDA compliance in terms of requesting to see the ID. Overall, the ID requests increased from $23.5 \%$ to $30.9 \%$. This improvement was especially evident in the stores that received the intervention by SMI, regardless of whether the inspector revealed himself or not (Figure 3).

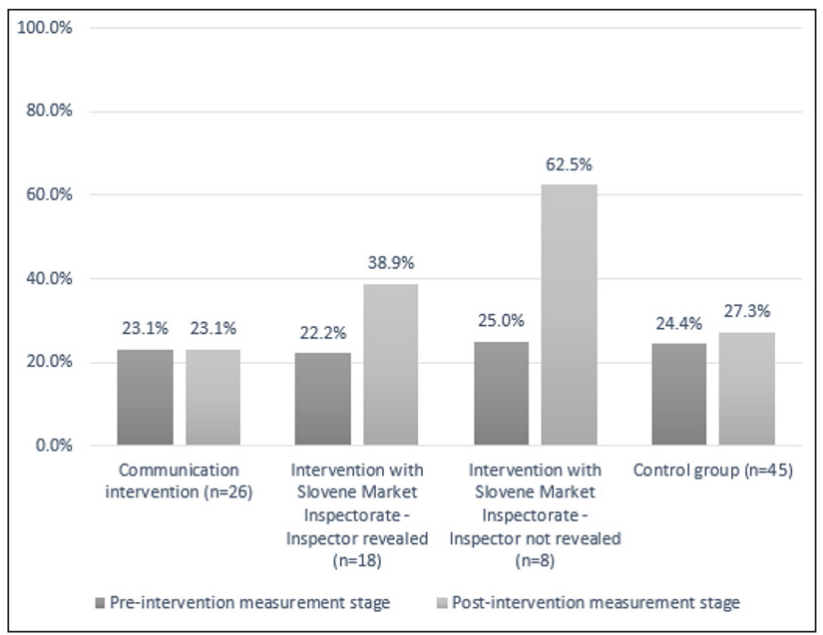

Figure 3. The rate of cashiers requesting to see the minors' (mystery shoppers') IDs according to intervention type in the pre- and post-intervention measurement stages.

After the interventions, we observed an improvement in the refusal of alcohol sales after requesting to see an ID (Figure 4). In the group that received the communication intervention, the number of ID requests followed by refusals of sale increased from $3.8 \%$ to $7.7 \%$. In the group that received the SMI intervention, when the inspector revealed himself, the increase was from $5.6 \%$ to $33.3 \%$.
The occasions when cashiers, despite checking the minors' IDs, sold the alcohol decreased from $16.7 \%$ to $5.6 \%$. In both of these groups, the occasions when cashiers checked the IDs and still sold the alcohol decreased (Figure 4).

The analysis showed that the correlation between the cashiers' ID requests and refused alcohol sales was statistically significant in both the pre-intervention measurement stage $(x=31.38, p<.001)$ and the postintervention measurement stage $(x=48.42, p<.001)$.

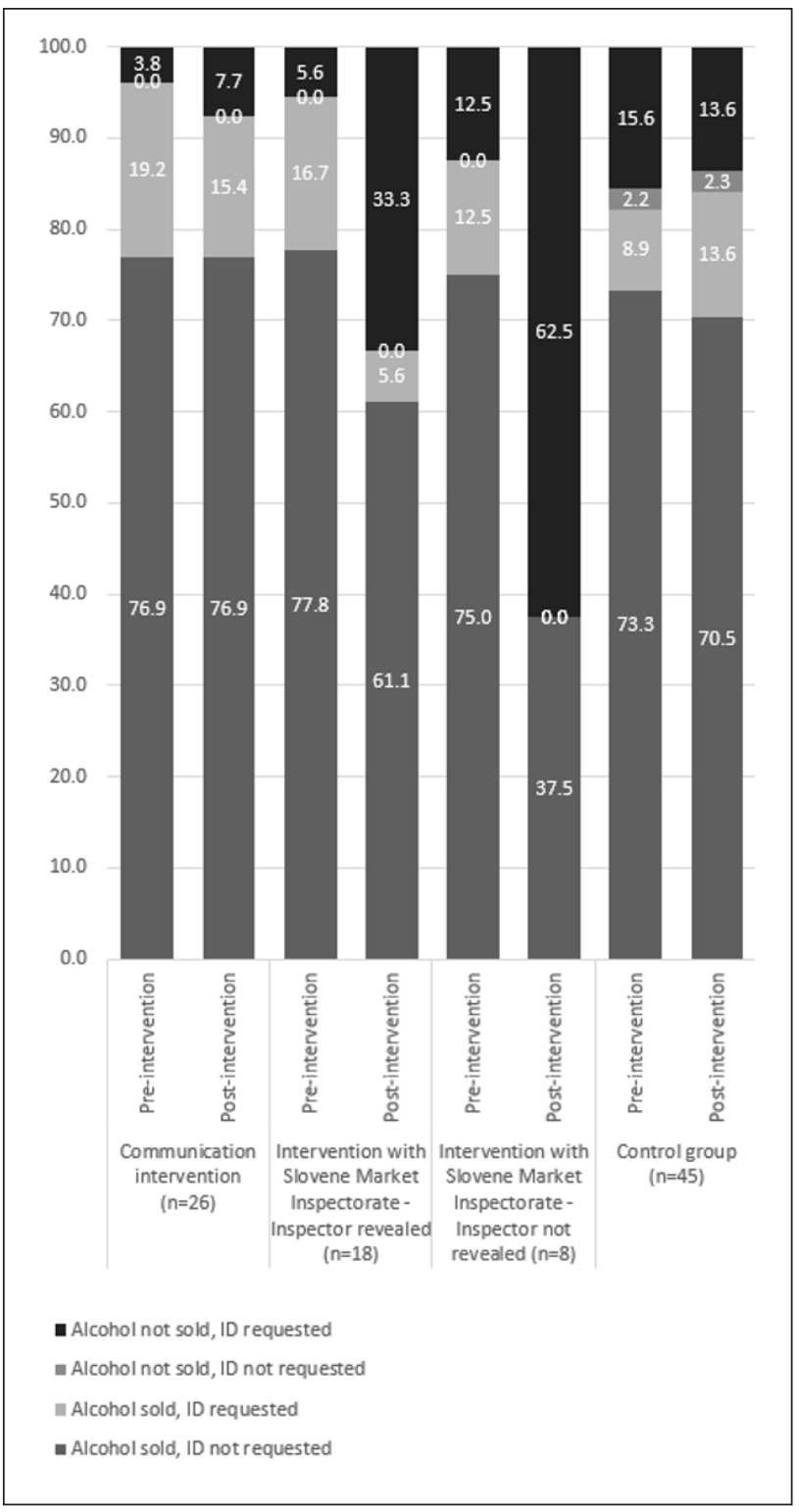

Figure 4. Detailed analysis of cashiers' requests for minors' (mystery shoppers') IDs and alcohol sales according to intervention type in the pre- and post-intervention measurement stages. 


\subsection{Alcohol purchases through the eyes of mystery shoppers}

The analysis of mystery shoppers' reports on the purchase interaction with cashiers, collected using the open-ended questions, in most cases revealed an absence of MLDAinformed dialogue between the young shoppers and cashiers. Exchanges mostly concerned the price of the purchase after the provision of the receipt. The most concerning observations in the reports were related to situations in which underaged shoppers were asked for their IDs and were still allowed to purchase the alcoholic beverage, regardless of their true ages being revealed. In these cases, the mystery shoppers reported that the cashiers accepted the ID and then (1) either stared at the ID for a while, without realising that the shopper was underaged, or (2) acknowledged the age but sold the alcoholic beverage anyway. In these cases, some cashiers accompanied the illegal sale by saying something to the effect of "Don't tell on me".

In instances when cashiers did not ask for an ID but only asked about the age of the young shopper, the mystery shoppers were instructed to say they were 18. In many cases this response sufficed, and the cashier sold the alcohol without asking to see the ID. In other cases, cashiers did ask to see the ID to check the claim of legal age. After learning the mystery shopper's actual age, they refused to sell the alcoholic beverage. The mystery shoppers also reported that some cashiers were apologetic after refusing the sale of the alcoholic beverage, explaining that they could get in trouble. In some cases, however, the cashiers expressed anger towards the mystery shoppers, sometimes even accusing the young shoppers of trying to get them in trouble.

\subsection{Qualitative insights: interviews with retail store managers and cashiers}

The analysis of the interviews with the store managers and cashiers about MLDA compliance in practice revealed that retailers received no official training regarding MLDA. The responsibility for emphasizing MLDA compliance falls onto the branch manager. In many cases, the managers delegated the responsibility for complying with the law to the cashiers based on their skills and personal experience. The cashiers reported it was hard to assess the age of the shoppers based on their looks; in many cases, they perceived it as a personal defeat when, after asking for an ID, the young person turned out to be 18 or over. The store managers mostly motivated their employees to comply with MLDA by reminding them of the legal penalties for failing to do so. All the branches received notifications from higher management when there was increased compliance control by the Inspectorate.

\section{DISCUSSION}

In line with previous studies of similar design (18), the initial MLDA noncompliance rate was high, which points to minors having easy access to alcohol in off-premise settings. In Slovenia, retailers' MLDA compliance is monitored by the SMI, but only occasionally. In 2014, the SMI found only 20 breaches of the law in 856 inspections made across the country, while a study with decoy youth shoppers in the same year found that retailers' MLDA compliance rate was only $8 \%$ (18). The SMI admitted that the compliance rate was much smaller than what their data showed (28), raising questions about the quality of their monitoring activities.

Our results showed that the tested interventions had a noticeable effect on compliance rates. We expected the communication intervention to have limited effects, as we were not able to conduct it according to the social marketing principles that demonstrated encouraging results in a previous study (18). The law enforcement intervention had greater effects, in line with previous studies from other countries, which found good MLDA compliance rates as long as law enforcement institutions (appeared to) maintain high detection rates of transgressors (19-24). The results of our second measurement were unsatisfactory, because many youth shoppers were still able to obtain alcohol. This brings us to the question of the penalties for breaking MLDA in Slovenia, which may need to be more severe.

Legislative regulations commonly attempt to influence behaviours by increasing the cost of undesired behaviours (29). The penalties for breaking MLDA should pose a serious threat to retailers' business models. One possibility would involve increasing the fines, but only if the frequency of checks by law enforcement agencies is high, which, according to previous data, is very unlikely $(24,25)$. A better solution would be to introduce revocable alcohol licenses for off-premise stores. This measure has proven to be effective and cost efficient elsewhere, (2) and could be a wise policy addition to MLDA in Slovenia as well.

Although strict MLDA compliance is necessary to reduce minors' access to alcohol, it should be noted that young people have access to alcohol in settings beyond the scope of MLDA. In Slovenia, as elsewhere, many young people have access to alcohol at home $(5,30)$. As easy home access to alcohol significantly predicts alcohol-related difficulties among young people (30), it would be wise to consider interventions to address the availability of alcoholic beverages to young people at home and other settings. Making MLDA more salient and more strictly enforced would send an important message to sellers, young consumers and the general public about the acceptability of alcohol consumption in society. It would thus be wise to adopt strategies for making MLDA consensually respected by both consumers and sellers. A possible positive strategy 
could involve publicising good practices in respecting MLDA, which would encourage stronger social norms about the desirability of respecting the law in this regard. A more educational approach could focus on building cashiers' capacities. Our qualitative results reveal that cashiers do not receive any official training that would equip them with the skills for MDLA compliance. We attempted to address this gap by developing educational materials for cashiers to help them with the conflicting situation in which they want to comply with both the young consumers' wishes and the MLDA. The cashiers who received the materials were grateful and evaluated them very positively. In line with previous research (18), our study shows the need to encourage cashiers to check the IDs of young consumers. Strict checking of young consumers' age is crucial because it leads to better MLDA compliance. By nudging the cashiers towards the desired behaviour, this process should be made as automatic as possible.

Despite its important findings, our study is limited because its sample was not representative, meaning that our results cannot be effectively generalized. Future studies could provide more generalizable results by relying on larger experimental groups and more evenly distributed interventions throughout different cities in Slovenia. Nonetheless, the results are indicative of a problem related to alcohol availability in off-premise commercial settings, a problem that the alcohol policy in Slovenia needs to continue to address via the following two of the five categories of actions (17): (1) policies that support education, communication, training and raising of public awareness, and (2) policies that regulate the alcohol market.

\section{CONCLUSION}

No single measure can address such a complex problem as alcohol consumption. If carried out in a systematic manner, several alcohol policy measures, such as limiting the availability of alcohol, can be effective in addressing alcohol-related problems. Alcohol policy measures could be implemented either using coercive and/or uncoercive means once the reasons for noncompliance are identified. In this study we aimed to improve the understanding of policy measures with regard to managing alcohol availability to young people in off-premise commercial settings in Slovenia. Moreover, we wanted to test MLDA compliance in selected shops, see which interventions could improve MLDA compliance, and shed light on the reasons for noncompliance with MLDA. Consequently, we discussed some implications for policy additions to MLDA and their possible implementation.

\section{CONFLICTS OF INTEREST}

The authors declare no conflicts of interest in relation to this study.

\section{FUNDING}

This study was financed by the Ministry of Health of the Republic of Slovenia as part of the No Excuse 2017-2019 program. The funding provider had no part in the study design, and is not responsible for the contents of the study in any way.

\section{ETHICAL APPROVAL}

The research focused on shopping processes and outcomes, and the nature of the study did not need the medical ethics committee's approval. At all stages of the research process, we followed the University of Ljubljana's code for research ethics (31). The parents whose underaged children participated in the study as mystery shoppers were asked to provide written informed consent.

\section{REFERENCES}

1. Lovrečič B, Lovrečič, M. Poraba alkohola in zdravstveni kazalniki tvegane in škodljive rabe alkohola: Slovenija, 2016. Ljubljana: NIJZ, 2018.

2. Roškar $M$, Blažko $N$, Kerstin Petrič $V$, Serec $M$, Hovnik Keršmanc $M$, Lovrečič $M$, et al. Alkoholna politika $v$ Sloveniji: priložnosti za zmanjševanje škode in stroškov ter neenakosti med prebivalci. Ljubljana, 2018.

3. Čebašek-Travnik, Z. Alkohol in druge droge kot javnozdravstveni problem. Delo + varnost. 2006;51:24-5.

4. Kolšek M, Ketiš ZK. Alcohol drinking among the students of the University of Maribor, Slovenia. Zdr Varst. 2015;54:259-66. doi: 10.1515/sjph-2015-0034.

5. Boben-Bardutzky D, Boben D, Čebašek-Travnik Z, Levačič $M$, Sorko $N$, Zorko M. Pot v odraslost - z ali brez alkohola?: rezultati raziskave o odnosu srednješolcev do alkohola. Ljubljana: Žarek upanja, 2010.

6. ESPAD. Availability of substances. ESPAD report 2015. “Do alcohol compliance checks decrease underage sales at neighboring establishments?" Accessed October 1st, 2020 at: http://www.espad. org/report/situation/availability-of-substances.

7. Hočevar T, Založnik P, Henigsman K, Roškar M. Poročanje o alkoholu v medijih: priporočila za javnozdravstveno ustrezno poročanje o alkoholnih pijačah v množičnih medijih. Ljubljana: NIJZ, 2020.

8. Kamin T, Roškar M. MOSA: addressing alcohol issues in Slovenia through an upstream multiple stakeholder approach. In: Knox K, Kubacki K, Rundle- Thiele S, editors. Stakeholder involvement in social marketing: challenges and approaches to engagement. Abingdon, New York: Routledge, 2021:55-71.

9. World Health Organization. Evidence for the effectiveness and cost-effectiveness of interventions to reduce alcohol-related harm. Copenhagen: WHO Regional Office for Europe, 2009. Accessed January 17th, 2021 at: https://www.euro.who.int/_data/assets/ pdf_file/0020/43319/E92823.pdf. 
10. Babor T, Caetano R, Casswell S, Edwards G, Giesbrecht N, Graham K, et al. Alcohol: no ordinary commodity - research and public policy. 2nd ed. Oxford: Oxford University Press, 2010.

11. Dent CW, Grube JW, Biglan A. Community level alcohol availability and enforcement of possession laws as predictors of youth drinking. Prev Med (Baltim). 2005;40:355-62. doi:10.1016/j.ypmed.2004.06.014.

12. Lipperman-Kreda S, Grube JW, Paschall MJ. Community norms, enforcement of minimum legal drinking age laws, personal beliefs and underage drinking: an explanatory model. J Community Health. 2010;35:249-57. doi: 10.1007/s10900-010-9229-6.

13. Kenny P, Hastings $G$. Understanding social norms: upstream and downstream applications for social marketers. In: Hastings G, Angus K, Bryant C, editors. Handbook of social marketing. Los Angeles, London: Sage, 2011:61-80.

14. Kuntsche E, Kuendig H, Gmel G. Alcohol outlet density, perceived availability and adolescent alcohol use: a multilevel structural equation model. J Epidemiol Community Health. 2008;62:811-6.

15. Bajt M, Zorko M. Uživanje alkoholnih pijač med mladostniki. Ljubljana, 2009. Accessed September 13th, 2014 at: http://www.zdravjevsoli.si/ attachments/article/173/fokusne porocilo_alkohol.pdf.

16. Jeriček Klanček H, Roškar M, Drev A, Pucelj V, Koprivnikar H, Zupanič $\mathrm{T}$, et al. Z zdravjem povezana vedenja $\mathrm{v}$ šolskem obdobju med mladostniki v Sloveniji: izsledki mednarodne raziskave HBSC 2018. Ljubljana: NIJZ, 2019.

17. Krnel SR, Kamin T, Košir M, Markič M. Stakeholders' interests identified through their views on the alcohol policy measures in Slovenia. $\mathrm{Zdr}$ Varst. 2010;49:86-98. doi: 10.2478/v10152-010-0009-6.

18. Kamin T, Kokole D. Midstream social marketing intervention to influence retailers' compliance with the minimum legal drinking age law. J Soc Mark. 2016;6:104-20. doi: 10.1108/JSOCM-05-2015-0030.

19. Wagenaar AC, Toomey TL, Erickson DJ. Preventing youth access to alcohol: outcomes from a multi-community time-series trial. Addiction. 2005;100:335-45. doi: 10.1111/j.1360-0443.2005.00973.x.

20. Montgomery JM, Foley KL, Wolfson M. Enforcing the minimum drinking age: state, local and agency characteristics associated with compliance checks and Cops in Shops programs. Addiction. 2006;101:223-31. doi: 10.1111/j.1360-0443.2006.01328.x.

21. Paschall MJ, Grube JW, Black C, Flewelling RL, Ringwalt CL, Biglan A. Alcohol outlet characteristics and alcohol sales to youth: results of alcohol purchase surveys in 45 Oregon communities. Prev Sci. 2007;8:153-9.

22. Huckle T, Conway K, Casswell S, Pledger M. Evaluation of a regional community action intervention in New Zealand to improve age checks for young people purchasing alcohol. Health Promot Int. 2005;20:14755. doi: 10.1093/heapro/dah610.

23. Schelleman-Offermans K, Knibbe RA, Kuntsche E, Casswell S. Effects of a natural community intervention intensifying alcohol law enforcement combined with a restrictive alcohol policy on adolescent alcohol use. J Adolesc Heal. 2012;51:580-7. doi: 10.1016/j. jadohealth.2012.03.006.

24. Erickson DJ, Smolenski DJ, Toomey TL, Carlin BP, Wagenaar AC. Do alcohol compliance checks decrease underage sales at neighboring establishments? J Stud Alcohol Drugs. 2013;74:852-8. doi: 10.15288/ jsad.2013.74.852.

25. Mulder J, de Greeff J, Borgesiuslaan G. Eyes on age: a research on alcohol age limit policies in European member states: legislation, enforcement and research. Brussels, 2013.

26. Van Hoof JJ, Gosselt JF, Baas N, De Jong MDT. Improving shop floor compliance with age restrictions for alcohol sales: effectiveness of a feedback letter intervention. Eur J Public Health. 2011;22:737-42. doi: 10.1093/eurpub/ckr162.

27. Braun V, Clarke V. Using thematic analysis in psychology. Qual Res Psychol. 2006;3:77-101. doi: 0.1191/1478088706qp063oa.
28. TIRS. Yearly report of the market inspectorate of the republic of Slovenia. Ljubljana; 2015. Accessed October 10th, 2020 at: https://www.gov.si/assets/organi-v-sestavi/TIRS/Poslovnaporocila/673dd09edf/TirsPoslovnoPorocilo2014.pdf.

29. Lee NR, Rothschild ML, Smith W. A declaration of social marketing's unique principles and distinctions. 2011. Accessed October 1st, 2020 at: http://www.hwctf.org/Lee N R et al 2011 A Declaration of Social Marketings Unique Principles and Distinctions.pdf.

30. Hoskin AW, Moody D. The association between home alcohol access and alcohol-related problems among US adolescents. J Subst Use. 2020;25:246-50.

31. Univerza $\vee$ Ljubljani. Etični kodeks za raziskovalce. Ljubljana: Univerza v Ljubljani, 2014. 